Jurnal SainHealth Vol. 3 No. 2 Edisi September 2019

(C) Fakultas Ilmu Kesehatan Universitas Maarif Hasyim Latif Sidoarjo

p-ISSN : 2548-8333

e-ISSN : 2549-2586

\title{
ANALISIS RESIDU ANTIBIOTIK TETRASIKLIN PADA DAGING AYAM BROIIER DAN DAGING SAPI
}

\author{
Siti Nur Aniza ${ }^{1)}$, Ary Andini ${ }^{1{ }^{*}}$, Indah Lestari ${ }^{2)}$ \\ ${ }^{1}$ Program Studi D-IV Analis Kesehatan, Universitas Nahdlatul Ulama Surabaya \\ ${ }^{2}$ Program Studi D-IV Analis Kesehatan, Poltekkes Kemenkes Surabaya \\ e-mail : \\ aryandini@unusa.ac.id
}

\begin{abstract}
Tetracycline are antibiotics with broad-spectrum that used routinely in veterinary medicine for animal treatment and prevention from infectious diseases. But, consuming antibiotics for long time and exceeding standards can lead to accumulation of antibiotic residues in the body. Based on SNI 01-6366-2000, the maximum residual limit (BMR) of tetracycline antibiotic is $0.1 \mathrm{mg} / \mathrm{kg}$ in meat.The purpose of this study was to determine the concentration of tetracycline residues in broiler chicken meat and beef that obtained in East Surabaya namely Manyar market, Sinar Baru market, Ampengan Batu market, Tenggilis Mejoyo market, Krempyeng market, Soponyono market, and Gunung Anyar market. This study used Thin Layer Chromatography (TLC) as qualitative test and Spectrophotometric method as a quantitative test to determine the residual levels of tetracycline antibiotics. This study was conducted on March 15 onto May 2 2019. Based on the study, about 32 broiler chicken and 13 beef samples detected by the TLC method showed that had negative results, there was no containing tetracycline residues in samples. Awhile the results of the spectrophotometric method showed that as many as 31 samples of broiler chicken and 13 beef samples showed that had positive results containing residues of tetracycline antibiotics that exceed of the standard. Based on the results obtained that average concentration of tetracycline in samples of broiler chicken meat about $1,7 \mathrm{mg} / \mathrm{kg}$ and $0,8 \mathrm{mg} / \mathrm{kg}$ in beef samples. Descriptively,tetracycline residues in broiler chicken meat were higher than beef. Keywords: Tetracycline, Chicken, Cow, Thin Layer Chromatography, Spectrophotometric
\end{abstract}

\section{PENDAHULUAN}

Daging merupakan bahan pangan yang berasal dari hewan yang menjadi salah satu kebutuhan pokok bagi kehidupan manusia karena memiliki kandungan gizi dan sebagai sumber protein hewani. Protein hewani mengandung asam-asam amino esensial yang dibutuhkan manusia dan lebih mudah untuk dicerna (Iwantoro dan Etikaningrum, 2017). Produk hewan yang berkualitas akan mampu mempunyai nilai jual yang tinggi dan berkompetisi di dalam perdagangan secara luas. Namun, dewasa ini masih banyak permasalahan yang berkaitan dengan mutu dan keamanan produk hewan diantaranya yaitu tingginya kasus keracunan makanan, adanya produk yang tidak memenuhi syarat mutu dan keamanan karena tercemar bahan kimia dan mikroba, 
dan penanganan rantai produksi yang kurang baik (Dewi, 2014).

Salah satu bahan kimia yang dapat mencemari produk hewan adalah residu antibiotik. Residu antibiotik dalam pangan dapat mengancam kesehatan masyarakat. Ancaman tersebut berupa dampak negatif yang berakibat kepada masyarakat, diantaranya yaitu terjadinya resistensi bakteri, alergi terhadap pangan dan juga keracunan. Masalah residu antibiotik timbul pada produk pangan hewan diakibatkan oleh pengaplikasian antibiotik yang kurang tepat pada hewan-hewan ternak. Antibiotik digunakan untuk pengobatan dan juga pemacu pertumbuhan ternak, sehingga apabila penggunaan antibiotik yang tidak memperhatikan masa henti obat, maka akan menimbulkan terbentuknya residu antibiotik pada produk pangan hewan (Dewi, 2014).

Jenis antibiotik yang paling sering ditemukan pada produk ternak khususnya daging ternak adalah antibiotik dari jenis tetrasiklin. Dalam industri peternakan, antibiotik seringkali digunakan untuk pengobatan penyakit pernafasan dan dalam dosis rendah dapat digunakan sebagai pemicu pertumbuhan hewan ternak. Pada dasarnya golongan tetrasiklin hanya diperbolehkan sebagai obat hewan dan tidak termasuk dalam daftar zat aditif pakan yang diizinkan di Indonesia, namun karena harganya yang murah dibandingkan dengan antibiotik yang diperbolehkan menjadi imbuhan pakan, maka golongan tetrasiklin juga banyak digunakan sebagai zat aditif imbuhan pakan (Iwantoro dan Etikaningrum, 2017). Badan Standarisasi Nasional (BSN, 2000) menetapkan bahwa waktu henti pemakaian antibiotik golongan tetrasiklin adalah lima hari menjelang ternak dipotong dan batas cemaran residu tetrasiklin pada daging sebesar $0,1 \mathrm{mg} / \mathrm{kg}$.

Penelitian ini bertujuan untuk mengetahui kadar residu antibiotik tetrasiklin pada daging ayam broiler ( $G$. domesticus) dan daging sapi (B. taurus) yang di jual di kawasan Surabaya Timur.

\section{METODE PENELITIAN}

Pada penelitian ini menggunakan desain penelitian observasional dengan pendekatan secara cross-sectional. Besar sampel yang digunakan adalah 32 sampel daging ayam broiler dan 13 sampel daging sapi yang diperoleh dari pasar yang berada di kawasan Surabaya Timur, diantaranya yaitu : pasar Manyar, pasar Sinar Baru, pasar Ampengan Batu, pasar Tenggilis Mejoyo, pasar Krempyeng, pasar Soponyono, dan pasar Baru Gunung Anyar.

Pada penelitian ini menggunakan metode kromatografi lapis tipis dan metode spektrofotometri. Penelitian ini dilaksanakan selama bulan Maret sampai dengan bulan Mei 2019.

Adapun alat-alat yang digunakan untuk pengujian tetrasiklin dengan KLT adalah beaker glass, telenan, pisau, spatula, batang pengaduk, kaca arloji, gelas ukur, pipet ukur, pump, labu ukur, tabung sentrifus, blender, neraca analitik, chamber, pipa kapiler, vortex dan sentrifus. Sedangkan alat-alat yang digunakan untuk pengujian kadar tetrasiklin dengan spektrofotometer UV-Vis adalah beaker glass, telenan, pisau, spatula, batang pengaduk, kaca arloji, magnetic stirrer, hot plate, Erlenmeyer, gelas ukur, pipet tetes, pipet ukur, pump, labu ukur, tabung sentrifus, blender, neraca analitik, dan spektrofotometri UV-Vis (Thermo Scientific, Madison, USA).

Bahan-bahan yang digunakan untuk pengujian dengan KLT adalah air suling, asam sitrat monohidrat, trinatrium sitrat, tetrasiklin hidroklorida baku (BPFI), plat kromatografi lapis tipis, kloroform, methanol, daging ayam broiler bagian paha dan daging sapi bagian lulur. Sedangkan bahan-bahan yang digunakan untuk dengan metode spektrofotometri adalah air suling, asam klorida $0,1 \mathrm{~N}$, asam sitrat monohidrat, dinatrium hydrogen pospat anhidrat, 
dinatrium EDTA dihidrat, tetrasiklin hidroklorida baku (BPFI), daging ayam broiler bagian paha dan daging sapi bagian lulur.

\section{Kromatografi Lapis Tipis}

Pengumpulan Sampel

Sampel yang diperiksa dalam penelitian ini adalah daging ayam broiler bagian paha dan daging sapi bagian lulur. Sampel di ambil dalam kondisi segar kemudian dibersihkan dari kulit dan tulangnya. Sebelum diperiksa, sampel dihaluskan terlebih dahulu dengan menggunakan blender.

\section{Ekstraksi Sampel}

Sampel yang sudah diperoleh dari pasar dibersihkan dari kulit dan tulangnya, kemudian dihaluskan dengan blender. Lalu sampel ditimbang sebanyak 5 gram dan ditambahkan $3 \mathrm{ml}$ buffer sitrat. Sampel dihomogenkan dengan vortex selama 5 menit dan diinkubasi selama 5 menit pada suhu ruang. Kemudian sampel disentrifus dengan kecepatan $3500 \mathrm{rpm}$ selama 10 menit dan supernatannya diambil. Proses ektraksi diulangi kembali dengan menambahkan $2 \mathrm{ml}$ buffer sitrat pada sampel.

\section{Penanganan Eluen dan Plat KLT}

Eluen yang digunakan dalam penelitian ini adalah kloroform : methanol (9:1). Eluen dijenuhkan dalam chamber selama $\pm 15-30$ menit. Plat KLT dipotong sesuai ukuran menggunakan pensil secara perlahan. Kemudian larutan standart tetrasiklin dan ekstrak sampel ditotolkan pada plat KLT menggunakan pipa kapiler secara perlahan. Plat KLT dimasukkan kedalam chamber dan dibiarkan hingga eluen sampai pada tanda batas atas. Setelah eluen mencapai batas atas, plat KLT dikeluarkan dari dalam chamber dan dikeringkan. Lalu diamati dibawah sinar UV dan dihitung nilai Rf-nya.

\section{Spektrofotometer UV-Vis}

Pengumpulan sampel

Sampel yang diperiksa dalam penelitian ini adalah daging ayam broiler bagian paha dan daging sapi bagian lulur. Sampel di ambil dalam kondisi segar kemudian dibersihkan dari kulit dan tulangnya. Sebelum diperiksa, sampel dihaluskan terlebih dahulu dengan menggunakan blender.

\section{Pembuatan larutan induk baku tetrasiklin $\mathrm{HCl}$ BPFI}

Tetrasiklin BPFI sebanyak $\pm 25,0 \mathrm{mg}$ ditimbang dengan seksama dan dimasukkan ke dalam labu ukur $50 \mathrm{ml}$. Kemudian tetrasiklin BPFI dilarutkan dengan asam klorida $0,1 \mathrm{~N}$ hingga mencapai batas garis tanda, sehingga diperoleh larutan dengan konsentrasi $500 \mu \mathrm{g} / \mathrm{ml}$. Larutan ini disebut larutan induk baku (LIB I). Dari larutan ini dipipet sebanyak 5,00 $\mathrm{ml}$ dan dimasukan ke dalam labu ukur $50 \mathrm{ml}$. Lalu 5,00 ml larutan tadi diencerkan dengan asam klorida $0,1 \mathrm{~N}$ hingga mencapai garis tanda sehingga diperoleh konsentrasi $50 \mu \mathrm{g} / \mathrm{ml}$ (LIB II).

\section{Penetapan panjang gelombang serapan} maksimum

Sejumlah 5,00 ml LIB II dipipet ke dalam labu ukur $25 \mathrm{ml}$, kemudian diencerkan dengan asam klorida $0,1 \mathrm{~N}$ hingga mencapai garis tanda. Selanjutnya larutan dikocok sampai homogen sehingga diperoleh larutan dengan konsentrasi 10 $\mu \mathrm{g} / \mathrm{ml}$. Kemudian larutan diukur serapannya pada panjang gelombang 200-400 nm.

\section{Ekstraksi sampel}

Sampel yang telah dihaluskan ditimbang sebanyak 20 g. Ditambahkan 40 $\mathrm{ml}$ buffer Mcllvaine-EDTA (pH 4), lalu dihomogenkan menggunakan magnetic stirrer selama 10 menit. Kemudia sampel disenttrifugasi dengan kecepatan $3500 \mathrm{rpm}$ selama 10 menit, dan supernatan diambil. Ditambahkan $20 \mathrm{ml}$ buffer Mcllvaine-EDTA dan disentrifugasi lagi dengan kecepatan 
3500 rpm selama 10 menit. Supernatan diambil dan endapan ditambahkan lagi dengan $20 \mathrm{ml}$ buffer Mcllvaine-EDTA dan disentrifugasi dengan kecepatan $3500 \mathrm{rpm}$ selama 10 menit. Supernatan yang diperoleh kemudian dikumpulkan dan disentrifugasi lagi dengan kecepatan 5000 rpm selama 20 menit. Hasilnya dimasukkan kedalam labu ukur $100 \mathrm{ml}$ dan dicukupkan dengan asam klorida $0,1 \mathrm{~N}$ hingga garis tanda.

Penetapan kadar residu tetrasiklin dalam daging ayam broiler dan daging sapi

Larutan sampel dipipet sebanyak 1,6 $\mathrm{ml}$ dan dimasukkan kedalam 5 labu ukur 10 ml. Larutan induk baku II ditambahkan $0 ; 1$; 1,$5 ; 2$; dan $2,5 \mathrm{ml}$, kemudian diencerkan menggunakan asam klorida $0,1 \mathrm{~N}$ hingga tanda batas. Masing-masing didapatkan larutan tetrasiklin $\mathrm{HCl}$ baku dengan konsentrasi $0 ; 5 ; 7,5 ; 10$; dan 12,5 $\mu \mathrm{g} / \mathrm{ml}$. Absorbansi dari masing-masing larutan diukur pada panjang gelombang $289 \mathrm{~nm}$. Selanjutnya dibuat grafik absorbansi dan konsentrasi standard ditentukan dengan persamaan regresi linier $\mathrm{y}=\mathrm{bx}+\mathrm{a}$.
Dengan mengekstrapolasikan garis pada sumbu $X$ (garis memotong sumbu $X$ ) atau mensubstitusikan absorbansi $(\mathrm{Y})=0$ pada persamaan regresi yang diperoleh maka akan diperoleh konsentrasi residu tetrasiklin dalam larutan sampel yang diukur (Cx). Kemudian hasilnya dikalikan dengan faktor pengenceran dan volume larutan sampel kemudian dibagi berat penimbangan sampel daging sehingga diperoleh kadar residu tetrasiklin dengan satuan $\mu \mathrm{g} / \mathrm{g}$ sampel atau dapat dinyatakan dalam rumus berikut :

Kadar Tetrasiklin $=\mathrm{Cx}(\mu \mathrm{g} / \mathrm{ml}) \times$ Fakt. Pengenceran x Vol. Sampel (ml)

Berat Sampel

\section{HASIL}

Hasil penelitian dari metode kromatografi lapis tipis dapat dilihat pada tabel 1 dan tabel 2. Sampel yang sudah diekstrak ditotolkan pada plat KLT $\mathrm{GF}_{254}$ dan dielusi dengan eluen kloroform dan methanol (9:1). Hasil penelitian yang diperoleh adalah 32 sampel daging ayam dan 13 sampel daging sapi adalah negatif (tidak mengandung antibiotik tetrasiklin). Tabel 1. Hasil uji kualitatif dengan KLT pada sampel daging ayam broiler

\begin{tabular}{cccc}
\hline No. & Kode Sampel Daging Ayam & Nilai Rf & Keterangan \\
\hline 1. & M1 & - & Negatif \\
2. & M2 & - & Negatif \\
3. & M3 & - & Negatif \\
4. & M4 & - & Negatif \\
5. & M5 & - & Negatif \\
6. & M6 & - & Negatif \\
7. & M7 & - & Negatif \\
8. & M8 & - & Negatif \\
9. & M9 & - & Negatif \\
10. & T1 & - & Negatif \\
11. & T2 & - & Negatif \\
12. & S1 & - & Negatif \\
13. & S2 & - & Negatif \\
14. & S3 & - & Negatif \\
15. & S4 & - & Negatif
\end{tabular}


Jurnal SainHealth Vol. 3 No. 2 Edisi September 2019

(C) Fakultas Ilmu Kesehatan Universitas Maarif Hasyim Latif Sidoarjo

p-ISSN : 2548-8333

e-ISSN : 2549-2586

\begin{tabular}{cccc}
\hline No. & Kode Sampel Daging Ayam & Nilai Rf & Keterangan \\
\hline 16. & R1 & - & Negatif \\
17. & R2 & - & Negatif \\
18. & R3 & - & Negatif \\
19. & R4 & - & Negatif \\
20. & R5 & - & Negatif \\
21. & R6 & - & Negatif \\
22. & R7 & - & Negatif \\
23. & R8 & - & Negatif \\
24. & R9 & - & Negatif \\
25. & R10 & - & Negatif \\
26. & R11 & - & Negatif \\
27. & R12 & - & Negatif \\
28. & G1 & - & Negatif \\
29. & G2 & - & Negatif \\
30. & A1 & - & Negatif \\
31. & B1 & - & Negatif \\
32. & B2 & - & Negatif \\
\hline Standard untuk nilai Rf tetrasiklin adalah 0,6 (Krismawati, dkk., (2015) dan
\end{tabular}

Tabel 2. Hasil uji kualitatif dengan KLT pada sampel daging sapi

\begin{tabular}{cccc}
\hline No. & Kode Sampel Daging Sapi & Nilai Rf & Keterangan \\
\hline 1. & M1 & - & Negatif \\
2. & T1 & - & Negatif \\
3. & S1 & - & Negatif \\
4. & S2 & - & Negatif \\
5. & R1 & - & Negatif \\
6. & R2 & - & Negatif \\
7. & R3 & - & Negatif \\
8. & R4 & - & Negatif \\
9. & R5 & - & Negatif \\
10. & R6 & - & Negatif \\
11. & A1 & - & Negatif \\
12. & B1 & - & Negatif \\
13. & B2 & - & Negatif \\
\hline
\end{tabular}

Keterangan : Standard untuk nilai Rf tetrasiklin adalah 0,6 (Krismawati, dkk., (2015) dan Dewi, dkk., (2015). 
Hasil penelitian dari metode spektrofotometri. Pada sampel yang sudah diekstrak, sebelum dilakukan pembacaan pada spektrofotometer UV-Vis, dilakukan penentuan panjang gelombang terlebih dahulu untuk digunakan pada tahapan penetapan kadar tetrasiklin pada sampel. Hasil pengukuran panjang gelombang maksimum menunjukkan pada $289 \mathrm{~nm}$. Hasil yang diperoleh dapat diamati pada gambar 3.

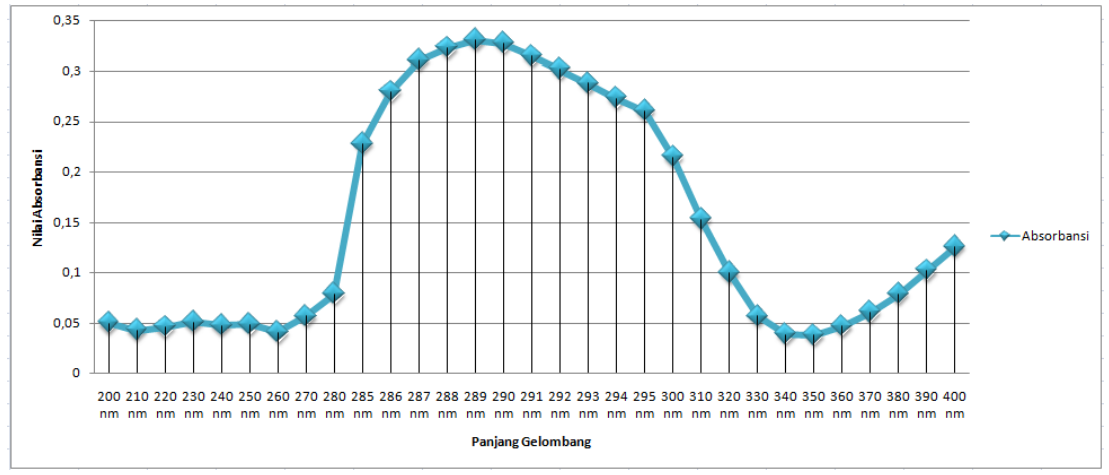

Gambar 1. Kurva penentuan panjang gelombang tetrasiklin

Berdasarkan penelitian yang dilakukan diperoleh hasil 31 sampel daging ayam broiler dan 13 sampel daging sapi positif mengandung residu tetrasiklin yang melebihi batas maksimal residu.kadar tetrasiklin. Hasil tersebut dapat diamati pada tabel 3 dan tabel 4. Berdasarkan hasil pada tabel 3 dan tabel 4 maka diperoleh rata-rata kadar tetrasiklin pada sampel daging ayam broiler adalah $1,7 \mathrm{mg} / \mathrm{kg}$ dan $0,8 \mathrm{mg} / \mathrm{kg}$ pada sampel daging sapi. Berdasarkan ketetapan Badan Stadarisasi Nasional (BSN) dalam SNI 01-6366-2000 menetapkan batas maksimal residu (BMR) antibiotik yang sesuai adalah $0,1 \mathrm{mg} / \mathrm{kg}$.

Tabel 3. Kadar tetrasiklin dalam daging ayam broiler

\begin{tabular}{cccc}
\hline No. & $\begin{array}{c}\text { Kode } \\
\text { Sampel }\end{array}$ & $\begin{array}{c}\text { Jumlah Kadar } \\
(\mathrm{mg} / \mathrm{kg})\end{array}$ & Keterangan \\
\hline 1. & M1 & 1,9 & Melebihi batas BMR \\
2. & M2 & 1,8 & Melebihi batas BMR \\
\hline 3. & M3 & 1,7 & Melebihi batas BMR \\
4. & M4 & 4,8 & Melebihi batas BMR \\
5. & M5 & 3,1 & Melebihi batas BMR \\
6. & M6 & 2,7 & Melebihi batas BMR \\
7. & M7 & 2,5 & Melebihi batas BMR \\
8. & M8 & 1,7 & Melebihi batas BMR \\
9. & M9 & 3,4 & Melebihi batas BMR \\
10. & T1 & 1,2 & Melebihi batas BMR \\
11. & T2 & 1,5 & Melebihi batas BMR \\
12. & S1 & 2,3 & Melebihi batas BMR \\
13. & S2 & 0,1 & Tidak melebihi batas BMR
\end{tabular}


Jurnal SainHealth Vol. 3 No. 2 Edisi September 2019

(C) Fakultas Ilmu Kesehatan Universitas Maarif Hasyim Latif Sidoarjo

p-ISSN : 2548-8333

e-ISSN : 2549-2586

\begin{tabular}{cccc}
\hline No. & $\begin{array}{c}\text { Kode } \\
\text { Sampel }\end{array}$ & $\begin{array}{c}\text { Jumlah Kadar } \\
(\mathrm{mg} / \mathrm{kg})\end{array}$ & Keterangan \\
\hline 14. & $\mathrm{~S} 3$ & 2,3 & Melebihi batas BMR \\
15. & S4 & 1,9 & Melebihi batas BMR \\
16. & R1 & 0,8 & Melebihi batas BMR \\
17. & R2 & 1,9 & Melebihi batas BMR \\
18. & R3 & 1,4 & Melebihi batas BMR \\
19. & R4 & 1,4 & Melebihi batas BMR \\
20. & R5 & 1,4 & Melebihi batas BMR \\
21. & R6 & 0,7 & Melebihi batas BMR \\
22. & R7 & 1,4 & Melebihi batas BMR \\
23. & R8 & 0,6 & Melebihi batas BMR \\
24. & R9 & 0,9 & Melebihi batas BMR \\
25. & R10 & 0,3 & Melebihi batas BMR \\
26. & R11 & 0,3 & Melebihi batas BMR \\
27. & R12 & 1,4 & Melebihi batas BMR \\
28. & G1 & 0,8 & Melebihi batas BMR \\
29. & G2 & 3,0 & Melebihi batas BMR \\
30. & A1 & 1,2 & Melebihi batas BMR \\
31. & B1 & 1,6 & Melebihi batas BMR \\
32. & B2 & 3,2 & Melebihi batas BMR \\
\hline Rata - Rata & 1,7 & Melebihi batas BMR \\
\hline
\end{tabular}

Keterangan : Badan Stadarisasi Nasional (BSN) menetapkan batas maksimal residu (BMR) antibiotik,

sesuai yang tecantum dalam SNI 01-6366-2000 adalah 0,1 mg/kg.

Tabel 4 Kadar tetrasiklin dalam daging sapi

\begin{tabular}{cccc}
\hline No. & $\begin{array}{c}\text { Kode } \\
\text { Sampel }\end{array}$ & $\begin{array}{c}\text { Jumlah Kadar } \\
(\mathrm{mg} / \mathrm{kg})\end{array}$ & Keterangan \\
\hline 1. & M1 & 1,2 & Melebihi batas BMR \\
2. & T1 & 0,8 & Melebihi batas BMR \\
3. & S1 & 0,7 & Melebihi batas BMR \\
4. & S2 & 0,7 & Melebihi batas BMR \\
5. & R1 & 1,0 & Melebihi batas BMR \\
6. & R2 & 1,1 & Melebihi batas BMR \\
7. & R3 & 0,5 & Melebihi batas BMR
\end{tabular}


Jurnal SainHealth Vol. 3 No. 2 Edisi September 2019

(C) Fakultas Ilmu Kesehatan Universitas Maarif Hasyim Latif Sidoarjo

p-ISSN : 2548-8333

e-ISSN : 2549-2586

\begin{tabular}{rccc}
\hline No. & $\begin{array}{c}\text { Kode } \\
\text { Sampel }\end{array}$ & $\begin{array}{c}\text { Jumlah Kadar } \\
(\mathrm{mg} / \mathrm{kg})\end{array}$ & Keterangan \\
\hline 8. & R4 & 0,8 & Melebihi batas BMR \\
9. & R5 & 0,2 & Melebihi batas BMR \\
10. & R6 & 0,3 & Melebihi batas BMR \\
11. & A1 & 0,7 & Melebihi batas BMR \\
12. & B1 & 1,1 & Melebihi batas BMR \\
13. & B2 & 0,9 & Melebihi batas BMR \\
\hline \multicolumn{2}{r}{ Rata - Rata } & 0,8 & Melebihi batas BMR \\
\hline
\end{tabular}

Keterangan : Badan Stadarisasi Nasional (BSN) menetapkan batas maksimal residu (BMR) antibiotic, sesuai yang tecantum dalam SNI 01-6366-2000 adalah 0,1 mg/kg. 


\section{PEMBAHASAN}

Metode kromatografi lapis tipis merupakan metode untuk mengidentifikasi senyawa berdasarkan kelarutannya. Pada metode KLT terdapat dua fase yaitu fase diam (plat silica gel) dan fase gerak. Sampel diekstraksi dengan menggunakan larutan buffer sitrat. Nilai $\mathrm{pH}$ pada buffer dapat memberikan pengaruh pada matriks sampel terhadap keberhasilan ekstraksi tetrasiklin. Menurut Shama et al., (2016), nilai pH optimum untuk ekstraksi berada pada rentang 3,5 dan 4,0. Interaksi pertukaran ion dari antibiotik yang diprotonasi mampu meningkat dalam lingkungan asam sehingga dapat meningkatkan efikasi ektraksi dari sampel. Sampel yang sudah diekstrak kemudian ditotolkan pada plat KLT $\mathrm{GF}_{254}$ dengan menggunakan eluen methanol dan kloroform (1:9) dan diamati dengan sinar UV.

Sebagai pembanding sampel, disertai dengan standart menggunakan tetrasiklin hidroklorida. Adapun nilai Rf yang terbentuk adalah 0,6. Hasil Rf sampel dinyatakan positif apabila warna bercak sampel dan baku pembanding sama atau saling mendekati dengan selisih $\leq 0,2$. Senyawa yang mempunyai nilai $\mathrm{Rf}$ besar dikarenakan memiliki kepolaran yang rendah, begitu pula sebaliknya senyawa yang memiliki kepolaran yang lebih tinggi akan tertahan kuat pada fasa diam sehingga menghasilkan nilai $\mathrm{Rf}$ yang lebih rendah.

Pengujian tetrasiklin dengan menggunakan metode KLT termasuk dalam uji secara kualititatif yang digunakan hanya sebagai identifikasi adanya tetrasiklin pada sampel daging sapi dan daging ayam. Hasil negative pada hasil pengujian dapat dikarenakan senyawa yang diujikan belum terlarut sempurna dalam pelarut yang digunakan sehingga tertahan kuat pada fase diam. Oleh karena itu, diperlukan uji secara kuantitatif untuk mengetahui secara detail kadar tetrasiklin yang terdapat di daging sapi dan ayam dengan menggunakan metode spektrofotometri.

Penelitian dengan metode spektrofotometri dilakukan ekstraksi kembali dengan sampel daging ayam broiler dan daging sapi yang berbeda dari metode KLT sebelumnya. Berdasarkan penelitian yang dilakukan oleh Nurhasnawati (2016), prosedur ekstraksi sampel diadopsi dari Laboratory Quality Assurance Division (2007). Ekstraksi sampel dimulai dengan pemisahan sampel dari kulit dan tulangnya, dilanjutkan dengan penghalusan sampel dengan blender dan kemudian ditambahkan buffer McIlvaineEDTA pH 4.

Penambahan EDTA dalam larutan buffer dimaksudkan untuk meningkatkan efisiensi ekstraksi sampel. Hal ini dikarenakan tetrasiklin mampu berikatan dengan protein dan membentuk konjugat, sehingga sukar diekstraksi dari matriks sampel. Kendala lain dalam ekstraksi tetrasiklin dari sampel daging yaitu terjadinya pembentukan kelat antara tetrasiklin dengan ion logam yang terkandung dalam matriks. Oleh karena itu, untuk ekstraksi sampel dan deproteinasinya memakai pelarut yang sedikit asam untuk membebaskan tetrasiklin yang terikat nonkovalen dengan makromolekul tersebut. EDTA juga mampu bersaing dengan tetrasiklin dalam membentuk kelat dengan logam.

Sampel yang sudah diekstrak, sebelum dilakukan pembacaan pada spektrofotometer UV-Vis, dilakukan penentuan panjang gelombang terlebih dahulu. Dalam menentukan panjang gelombang diukur serapan pada panjang gelombang 200-400 nm dan diperoleh panjang gelombang $289 \mathrm{~nm}$. Berdasarkan penelitian yang dilakukan diperoleh hasil kadar tetrasiklin dalam daging ayam dan daging sapi sesuai pada tabel 3 dan tabel 4. Dari 32 sampel daging ayam broiler yang diuji hampir keseluruhan positif mengandung residu tetrasiklin yang melebihi batas maksimal residu yang telah ditentukan dan hanya satu sampel yang negatif. Sedangkan untuk 13 sampel daging sapi seluruhnya juga positif mengandung residu tetrasiklin yang melebihi batas maksimal residu.

Badan Stadarisasi Nasional (BSN) dalam SNI 01-6366-2000 menetapkan batas maksimal residu (BMR) antibiotik yang sesuai adalah $0,1 \mathrm{mg} / \mathrm{kg}$. Berdasarkan tabel 3 dan tabel 4 diperoleh rata-rata kadar tetrasiklin pada sampel daging ayam broiler menunjukkan hasil $1,7 \mathrm{mg} / \mathrm{kg}$ dan pada daging sapi sebesar $0,8 \mathrm{mg} / \mathrm{kg}$. Secara analisa deskriptif kadar residu antibiotik tetrasiklin pada sampel daging 
ayam broiler lebih tinggi dari pada sampel daging sapi.

Apabila dibandingkan dengan hasil uji secara kualitatif menggunakan KLT dan uji secara kuantitatif metode spektrofotometri dapat diketahui bahwa penentuan kadar tetrasiklikn pada sampel daging sapi dan ayam dengan metode spektrofotmetri lebih unggul daripada KLT. Hal ini karena hasil uji KLT hanya dinyatakan dalam positif $(+)$ atau negative (-) berdasarkan nilai $\mathrm{Rf}$ yang didapatkan dan hasil ini masih kurang representatif. Prinsip kerja KLT berdasarkan sifat kepolaran suatu senyawa, sehingga apabila suatu senyawa yang ingin diujikan tidak terlarut sepenuhnya ke pelarut atau encer maka hasil yang didapatkan bisa menjadi negative. Oleh karena itu, hasil uji dengan menggunakan metode spektrofotometri lebih dapat diakui jika dibandingkan dengan KLT

Penggunaan antibiotic pada hewan ternak baik pada ayam dan sapi diperuntukkan guna meningkatkan pertumbuhan hewan ternak, dan perawatan serta pengobatan dari penyakit serius akibat infeksi bakteri dan jamur pada hewan ternak (Siswanto dan Sulabda, 2017).

Residu antibiotik pada daging ayam dan sapi terjadi akibat penggunaan antibiotik yang digunakan sebagai pengobatan dan kontrol untuk penyakit infeksi yang tidak memperhatikan waktu henti obat, penggunaan antibiotik yang melebihi dosis, serta penggunaan antibiotik sebagai feed additive dalam pakan hewan (Martaleni, 2007; Masrianto dkk, 2013. Faktor-faktor yang mempengaruhi distribusi obat dalam tubuh ternak yaitu, perfusi darah melalui jaringan, kadar gradien, $\mathrm{pH}$ dan ikatan zat dengan makromolekul, partisi ke dalam lemak, transpor aktif, barier (sawar) dan ikatan obat dengan protein plasma atau jaringan.

Pakan yang mengandung antibiotik akan berinteraksi dengan jaringan (organ) dalam tubuh ternak, meskipun dalam jumlah yang kecil pengaruh yang ditimbulkan tidak secara langsung tetapi akan berefek kronis dan tetap berada dalam tubuh ternak. Senyawa induk dan metabolitnya sebagian akan dikeluarkan dari tubuh melalui air seni dan feses, tetapi sebagian lagi akan tetap tersimpan di dalam jaringan (organ tubuh) yang disebut sebagai residu. Jika pakan dicampur antibiotik secara terus menerus, maka residu antibiotik tersebut akan terakumulasi di dalam jaringan dengan konsentrasi yang bervariasi antara organ tubuh.

\section{UCAPAN TERIMAKASIH}

Terima kasih kepada staff Laboratorium Kimia Kesehatan, Fakultas Kesehatan, Universitas Nahdlatul Ulama Surabaya yang telah membantu dalam pelaksanaan penelitian.

\section{KESIMPULAN}

Analisa residu antibiotik tetrasiklin dengan metode KLT menunjukkan hasil negatif pada 32 sampel daging ayam broiler dan 13 sampel daging sapi. Sedangkan dengan metode spektrofotometri menunjukkan hasil rata-rata $1,7 \mathrm{mg} / \mathrm{kg}$ pada sampel daging ayam broiler dan $0,8 \mathrm{mg} / \mathrm{kg}$ pada sampel daging sapi. Secara analisa deskriptif kadar residu antibiotik tetrasiklin pada sampel daging ayam broiler lebih tinggi dari pada sampel daging sapi.

\section{REFERENSI}

Badan Standarisasi Nasional (BSN). 2000. Standar Nasional Indonesia 01-63662000 : Batas maksimal cemaran mikroba dan batas residu dalam bahan makanan asal hewan.

Dewi, A. A. S. ,Widdhiasmoro,N.P., Nurlatifah,I., Riti, N., Purnawati, D. 2014. Residu Antibiotika pada Pangan Asal Hewan, Dampak, dan Upaya Penanggulangan nya. Buletin Veteriner Vol. XXVI, No. 85

Dewi, T. M, Herawati, D., dan Hamdani, S. 2015. Analisis Kualitatif Antibiotika Tetrasiklin pada Madu. Prosiding Penelitian Sivitas Akademika.

Dewi, T. M., Herawati, D. dan Hamdani S. 2015. Analisis Kualitatif Residu Antibiotika Tetrasiklin pada Madu. Prosiding Penelitian SPeSIA hlm. 9-13

Etikaningrum dan Iwantoro, S. 2017. Kajian Residu Antibiotika pada Produk Ternak Unggas di Indonesia. Jurnal Ilmu Produksi dan Teknologi Hasil Peternakan Vol. 5 No.1 hlm. 29-33 
Martaleni. 2007. Deteksi Residu Antibiotika pada Karkas, Organ, dan Kaki Ayam Pedaging yang di Peroleh dari Pasar Tradisional kabupaten Tangerang. Skripsi. Institut Pertanian Bogor : Bogor

Masrianto. Fakhrurrazi.Azhari. 2013. Uji Residu pada Daging Sapi yang di Pasarkan di Pasar Tradisional Kota Banda Aceh, Jurnal Medika Veterinaria, Vol 7, No. 1

Nofita, Rinawati, dan Qudus. 2016. Validasi Metodematrix Solid Phase Dispersion (Mspd) Spektrofotometri Uv Untuk Analisis Residu Tetrasiklin Dalam Daging Ayam Pedaging. Jurnal Kesehatan, Vol. VII, No. 1, hlm 136-143

Nurhasnawati, Henny, Jubaidah Siti, dan Elfia, N. 2016. Penentuan Kadar Residu Tetrasiklin $\mathrm{HCl}$ pada Ikan Air Tawar yang Beredar di Pasar Segiri Menggunakan Metode Spektrofotometri Ultra Violet. Jurnal Ilmiah Manuntung. Vol. 2 No. 2 hlm 173-178

Shama, S.A., El Sharkawy, Abd el Azim S., Mahmoud, A.H., Hassan, Heba M., Nassar, dan Shaimaa H. 2016. Validation on Modified HPLC Method for Detemination of Oxytetracycline, Tetracycline and Doxycycline in Chicken Meat and Liver. New York Science Journal. Vol. 9 No. 5

Siswanto. Sulabda, IN. 2017. Kadar Residu Antibiotik dalam Daging Sapi Bali di Beberapa Pasar di Bali. Manuskrip. Fakultas Kedokteran Hewan, Universitas Udayana, Denpasar, Bali 